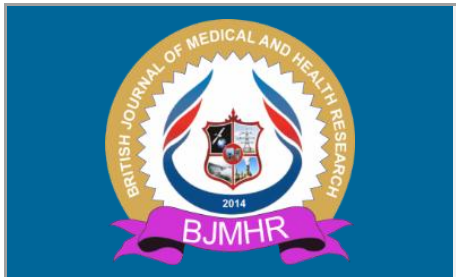

\title{
BJMHR
}

British Journal of Medical and Health Research Journal home page: www.bjmhr.com

\section{Partial Purification of Extracellular Lipase from Soil Fungal Isolate}

\section{Shreya $^{1}$, Arun Kumar Sharma ${ }^{1 *}$, Vinay Sharma ${ }^{3}$, Jyoti Saxena ${ }^{2}$ \\ 1.Department of Bioscience and Biotechnology, Banasthali Vidyapith, Rajasthan, India 2.Department of Biochemical Engineering, Bipin Tripathi Kumaon Institute of Technology, Dwarahat, Uttrakhand 3.Amity University, Rajasthan}

\begin{abstract}
Lipases are biotechnologically vital cluster of enzymes reported to be produced by many species of animals, plants, bacteria, yeasts and fungi. Lipases of microbial origin that are employed in the detergent, dairy, cosmetic, food, and tanning industries are mostly engaging. The present study was aimed at partial purification of lipase produced from soil fungal isolate. Hyper producer strain was selected by growing fungal isolate onto the tributyrin agar media plates. Extracellular lipase was produced by inoculating the isolated strain in fermentation broth followed by incubation at $28^{\circ} \mathrm{C}$ for 5 days at $120 \mathrm{rpm}$. Mycelium free culture supernatant obtained after centrifugation of fungus broth was used for purification study. Among the ammonium sulphate precipitates, $60 \%$ fractionate showed the highest lipase activity and protein content, and on further dialysis the lipase activity was increased. 2.78 fold purification was obtained by $60 \%$ ammonium sulphate dialyzed precipitation which is higher than the fold purification of crude lysate.
\end{abstract}

Keywords: Crude lysate, fungi, lipases, partial purification.

*Corresponding Author Email: arun.k.sharma84@gmail.com

Received 21 March 2018, Accepted 15 April 2018

Please cite this article as: Shreya et al., Partial Purification of Extracellular Lipase from Soil Fungal Isolate. British Journal of Medical and Health Research 2018. 


\section{INTRODUCTION}

Lipases (triacylglycerol acylhydrolase, EC 3.1.1.3) are a biotechnologically vital cluster of enzymes that act on the carboxyl organic compound bonds present in triacylglycerols and liberate fatty acids and alcohol. ${ }^{1}$

Lipases are reported to be produced by many species of animals, plants, bacteria, yeasts and fungi. ${ }^{2}$ Among these, microbial lipases have gained wide industrial applications in view of high yields, rapid growth of microorganisms and ease of genetic manipulation. ${ }^{3}$

Lipases chemical action potentials are monstrous. Lipases of microbial origin that are employed in the detergent, diary, cosmetic, food, and tanning industries are mostly engaging. In view of their recent and potential applications, lipases are thought to be a promising category of commercial enzymes. ${ }^{4}$

The purification of lipase from culture filtrate was reported by SDS-PAGE and disc-PAGE. ${ }^{5}$

The purification included gel filtration, SP-Sephadex and isoelectric focusing and obtain improved yield was 38\%. $31 \mathrm{KDa}$ molecular weight of protein was determined by SDS-PAGE. 134 fold purification of extracellular lipase present in production broth was estimated through ammonium sulphate precipitation, gel permeation and ion exchange chromatography with yield of $46 \%{ }^{6}$

$33.7 \%$ yield was obtained by partial ammonium sulphate precipitation and ion exchange chromatography. $90 \mathrm{KDa}$ molecular weight of lipase was determined and optimum activity at pH 7 and $40^{\circ} \mathrm{C}$. By keeping immense applications of lipase in our mind we have produced lipase by soil fungi followed by ammonium sulphate precipitation, dialysis and acetone precipitation. $^{7}$

\section{MATERIALS AND METHOD}

All chemicals and glassware's were used from Rankem, Sigma Aldirich, SRL, TM media, Hi media, Borosil and Riviera.

\section{Sample collection}

The soil sample was collected from petrol pump, Newai (Raj). Soil sample was collected with sterile spatula in a sterile plastic bag and stored in refrigerator at $4^{\circ} \mathrm{C}$ until use.

\section{Isolation of lipolytic fungi}

Isolation of lipolytic fungi was done by serial dilution and spread plate method. PDA plates were incubated at $28^{\circ} \mathrm{C}$ for 5-7 days in inverting condition. ${ }^{8}$

\section{Screening of lipase producing fungi}

The pure fungal isolates were screened onto tributyrin agar (TBA) plates. TBA plates were point inoculated with fungal isolates and were incubated at $28^{\circ} \mathrm{C}$ for $4-5$ days in inverted 
condition. After incubation plates were analyzed for appearance of clear zone around the colonies. ${ }^{9}$

\section{Production of extracellular lipase from submerged fermentation}

Highest zone of clearance produced strain was selected and grown in culture media. One $\mathrm{ml}$ of spore suspension was inoculated in $100 \mathrm{ml}$ of production medium which was prepared by dissolving (4 $\mathrm{g}$ of peptone, $0.1 \mathrm{~g}$ of $\mathrm{MgSO}_{4} .7 \mathrm{H}_{2} \mathrm{O}, 0.1 \mathrm{~g}$ of $\mathrm{KH}_{2} \mathrm{PO}_{4}, 0.1 \mathrm{~g}$ of $\left(\mathrm{NH}_{4}\right)_{2} \mathrm{SO}_{4}, 0.5 \mathrm{~g}$ of Sucrose, $1 \mathrm{ml}$ of olive oil) under aseptic conditions and $\mathrm{pH}$ was adjusted to $6.5 \pm 0.2$. Inoculated flasks were kept in shaking incubator at $120 \mathrm{rpm}, 28^{\circ} \mathrm{C}$ for $6-7$ days. ${ }^{10}$

\section{Preparation of crude protein lysate}

Fermentation broth from inoculated flask was filtered by using Whatmann filter paper No. 1 to remove mycelium network. Filtrate was centrifuged at $10,000 \mathrm{rpm}$ for $10 \mathrm{~min}$. at $4^{\circ} \mathrm{C}$. Pellet was discarded and supernatant was considered as crude protein lysate for determination of and lipase activity and protein content. ${ }^{11}$

\section{Partial purification of extracellular lipase}

\section{Acetone precipitation}

The crude enzyme lysate was subjected to $60 \%(\mathrm{v} / \mathrm{v})$ fractionate by adding chilled acetone and mixed with continuous stirring and left overnight at $4^{\circ} \mathrm{C}$. The ensuing acetone precipitate was centrifuged at $10,000 \mathrm{rpm}$ for $20 \mathrm{~min}$ at $4^{\circ} \mathrm{C}$. This resulted in pellet formation and was dissolved in minimal amount of tris $\mathrm{HCl}$ buffer $(0.02 \mathrm{M}, \mathrm{pH})$. The lipase activity and protein content was determined in pellet and supernatant both.

\section{Ammonium sulfate precipitation}

The crude enzyme lysate was subjected to different fractionate $(60 \%, 80 \%$ and $90 \%)$ of salt saturation by adding solid ammonium sulfate calculated through given formula. Resultant precipitates of each fractionate was centrifuged at $10,000 \mathrm{rpm}$ for $20 \mathrm{~min}$ at $4^{\circ} \mathrm{C}$ and dissolved in minimum amount of tris $\mathrm{HCl}$ buffer $(0.02 \mathrm{M}, \mathrm{pH} 7)$ further dialyzed extensively against the same buffer overnight at $4^{\circ} \mathrm{C}$. The lipase activity was calculated after each fractionate in both pellet and supernatant.

$$
\text { Grams of }\left(\mathrm{NH}_{4}\right)_{2} \mathrm{SO}_{4}=\frac{533 \times\left(\mathrm{S}_{2}-\mathrm{S}_{1}\right)}{100-0.3 \times \mathrm{S}_{2}}
$$

Where, $S_{1}$ is initial percent salt concentration and $S_{2} 1$ s percent salt saturation we want to obtain. This equation is based on assumption that $100 \%$ saturation is equal to $4.05 \mathrm{M}\left(\mathrm{NH}_{4}\right)_{2} \mathrm{SO}_{4}$. In order to determine, how much pure protein we get as compared to crude lysate fold purification and \% yield were calculated using given formulas. 


$$
\begin{aligned}
\text { Fold purification } & =\frac{\text { Specific Activity of each fraction }}{\text { Specific Activity of crude protein lysate }} \\
\% \text { Yield } & =\frac{\text { Total enzyme activity of each fraction }}{\text { Total enzyme activity of crude protein lysate }} \times 100
\end{aligned}
$$

\section{Dialysis}

Fraction of ammonium sulphate precipitation was subjected to dialysis to remove the residual impurities from the purified enzyme mixture. Dialysis membrane (cut off value 10KDa) was used. One end of the membrane was tied up with thread and enzyme was poured into the dialysis membrane. The other end of membrane was tied securely. The membrane was put into the $200 \mathrm{ml}$ of tris HCL buffer $(0.02 \mathrm{M}, \mathrm{pH} 7)$ and was kept on magnetic stirrer for 2 hours at room temperature. The buffer was replaced after 2 hours and it was left overnight. The enzyme activity and protein content was checked.

\section{RESULTS AND DISCUSSION}

The partial purification process and results are summarized in Table 1. Crude lysate was fractionate and dialyzed to get enzyme activity. Lipase activity and protein content was checked in each fractionate. $60 \%$ ammonium sulfate precipitation shown highest lipase activity among all different fractionates. $60 \%$ ammonium sulfate was followed by dialysis which resulted in increase of lipase activity $(15.48 \pm 0.11 \mathrm{IU} / \mathrm{ml} / \mathrm{min}) .2 .78$ fold purification was obtained by the purification process of $60 \%$ dialysate.

Table 1: Purification table showing ammonium sulphate precipitation, dialysis and acetone precipitation of crude enzyme extract.

\begin{tabular}{lllllllll}
\hline Steps & $\begin{array}{l}\text { Vol } \\
(\mathbf{m l})\end{array}$ & $\begin{array}{l}\text { Lipase } \\
\text { activity } \\
\text { IU/ml/min }\end{array}$ & $\begin{array}{l}\text { Protein } \\
\text { contents } \\
\text { mg/ml }\end{array}$ & $\begin{array}{l}\text { Total } \\
\text { acivity } \\
\text { Units } \\
* \mathbf{m l}\end{array}$ & $\begin{array}{l}\text { Total } \\
\text { protein } \\
\text { content } \\
* \mathbf{m l}\end{array}$ & $\begin{array}{l}\text { Specific } \\
\text { activity } \\
\text { U/mg }\end{array}$ & $\begin{array}{l}\text { Fold } \\
\text { purification }\end{array}$ & $\begin{array}{l}\text { \% } \\
\text { yield }\end{array}$ \\
\hline $\begin{array}{l}\text { Crude protein lysate } \\
\text { Ammonium sulphate precipitation }\end{array}$ & 100 & $6.89 \pm 0.09$ & 16.37 & 689 & 1637 & $0.41 \pm 0.005$ & 1 & \\
60\% fraction & 114 & $7.03 \pm 0.73$ & 22.08 & 801.42 & 2517.12 & $0.32 \pm 0.05$ & 0.78 & 116.31 \\
60\% supernatant & 112 & $1.93 \pm 0.26$ & 8.22 & 216.16 & 920.64 & $0.23 \pm 0.03$ & 0.56 & 31.51 \\
80\% fraction & 117 & $3.62 \pm 0.52$ & 21.58 & 423.54 & 2524.86 & $0.16 \pm 0.02$ & 0.39 & 61.47 \\
80\% supernatant & 115 & $2.62 \pm 0.82$ & 4.98 & 301.3 & 572.7 & $0.52 \pm 0.17$ & 1.26 & 43.73 \\
90\% fraction & 119 & $6.29 \pm 0.16$ & 7.44 & 784.51 & 885.36 & $0.84 \pm 0.03$ & 2.04 & 113.86 \\
90\% supernatant & 117 & $4.09 \pm 0.61$ & 0.42 & 478.53 & 49.37 & $1.16 \pm 0.12$ & 2.82 & 69.45 \\
Dialysis & & & & & & & & \\
Dialysis (60\% fraction) & 8.6 & $15.48 \pm 0.11$ & 13.53 & 133.12 & 116.35 & $1.14 \pm 0.02$ & 2.78 & 19.32 \\
$\begin{array}{l}\text { Dialysis (80\% fraction) } \\
\text { Dialysis (90\% fraction) }\end{array}$ & 4.8 & $10.25 \pm 0.39$ & 12.59 & 49.2 & 60.43 & $0.81 \pm 0.01$ & 1.97 & 7.14 \\
Acetone precipitation & 0.8 & $5.61 \pm 0.24$ & 4.11 & 4.48 & 3.28 & $1.36 \pm 0.10$ & 3.31 & 0.65 \\
\hline
\end{tabular}




\begin{tabular}{lllllllll}
\hline $60 \%$ fraction & 100 & $6.72 \pm 0.26$ & 9.97 & 672 & 997 & $0.67 \pm 0.02$ & 1.63 & 144.70 \\
$60 \%$ supernatant & 98 & $0.61 \pm 0.40$ & 8.43 & 59.78 & 826.14 & $0.04 \pm 0.02$ & 0.09 & 119.90 \\
\hline
\end{tabular}

Dialysis of $60 \%, 80 \%$ and $90 \%$ leads to an increase in specific activity and fold purification. $60 \%$ and $90 \%$ fractionate shown more $\%$ yield then crude protein lysate. The $90 \%$ ammonium sulphate fractionate show highest specific activity $(0.84 \pm 0.03 \mathrm{U} / \mathrm{mg})$ and 2.04 fold purification than crude enzyme lysate, and further dialysis increased activity $(1.36 \pm 0.10 \mathrm{U} / \mathrm{mg})$ and 3.31 fold purification. 1.63 fold purification was obtained by $60 \%$ acetone fraction precipitation higher than crude protein lysate.

In our experiment, we used ammonium sulfate for the fractionation step purification because of its solubility in water is higher due to its ionic character; therefore proteins are salted out by precipitation and called "salting out". Also used because it has ability to become more hydrated compared to non polar molecules and precipitate out of the solution. Exact amount of ammonium sulfate addition in the solution leads to precipitation of selectively protein while some remains soluble in solution.

Highest lipase activity was observed in all fractionate then in crude enzyme lysate. The highest fraction was F60 having value 12,283.33 U/mg protein and was used for further characterization process. ${ }^{12}$ Maximum specific activity (39.70 U/mg protein) was reported by ammonium sulfate precipitation then crude lysate. ${ }^{13}$ Similar to our result, more lipase activity was obtained after $60-80 \%$ dialyzed and obtained 2.9 fold purification. ${ }^{14}$

After the enzyme produced in production media it was subjected to ammonium sulphate precipitation for purification of proteins. It was obvious from the result that $60 \%$ supernatant ammonium sulphate exhibited more lipase activity then the crude lysate. ${ }^{15} 25.4 \mathrm{U} \mathrm{mL}^{-1}$ extracellular lipase was obtained after $80 \%$ ammonium sulphate precipitation. ${ }^{16}$

\section{CONCLUSION}

The main aimed of study was purification of extracellular lipase isolated from fungi of petrol pump soil sample. The $60 \%$ ammonium sulphate fractionates was acted as best inducer because it shows highest lipase activity $(7.03 \pm 0.73 \mathrm{IU} / \mathrm{ml} / \mathrm{min})$ and 0.78 fold purification and increased on dialyzed $15.48 \pm 0.11 \mathrm{IU} / \mathrm{ml} / \mathrm{min}$ with 2.78 fold purification. Column chromatography will be used in further research to obtain more purified lipase.

\section{ACKNOWLEDGMENTS}

We would like warmly to thank Professor Aditya Shastri, Vice-Chancellor, Banasthali Vidyapith for providing excellent research facilities.

\section{REFERENCES}

1. Abrunhosa L, Oliveira F, Dantas D, Goncalves C, Belo I. Lipase production by 
Aspergillus ibericususing olive mill wastewater. Bioprocess and Biosystems Engineering. 2013; 36: 285-291.

2. Sztajer H, Maliszewska I, Wieczorek J. Production of exogenous lipases by bacteria, fungi and actinomycetes. Enzyme and Microbial Technology. 1998; 10: 492-497.

3. Andualema B, Gessesse A. Microbial lipases and their industrial applications: review. Biotechnology. 2012; 11: 100-118.

4. Cihangir N, Sarikaya E. Investigation of lipase production by a new isolate of Aspergillus sp. World Journal of Microbiology \& Biotechnology. 1996; 20: 193-197.

5. Shimada Y, Tominaga Y. Purification and characterization of a novel strain-tolerant lipase from Fusarium heterosporum. Journal of Fermentation and Bioengineering. 1993; 75(5): 349-352.

6. Dey A, Chattopadhyay A, Mukhopadhyay SK, Saha P, Chatterjee S, Maiti TK. Production, Partial Purification and Characterization of an Extracellular Psychrotrophic Lipase from Pseudomonas Sp. ADT3. Journal Bioremediation \& Biodegradation, 2014; 5(6): 322-332.

7. Kashmiri MA, Adnan A, Butt BW. Production, purification and partial characterization of lipase from Trichoderma Viride. African Journal of Biotechnology. 2006; 5(10): 878-882.

8. Kumar D, Kumar L, Nagar S, Raina C, Prashad R, Gupta VJ. Screening, isolation and production of lipase/esterase producing Bacillus sp. strain DVL2 and its potential evaluation in esterification and resolution reactions. Archives of Applied Science Research. 2012; 4(4): 1763-1770.

9. Lestari P, Raharjo TJ, Matsjeh S, Haryadi W. Partial purification and biochemical characterization of extracellular lipase from Azospirillum sp. JG3 bacteria. American Institute of Physics. 2016; 1755(1).

10. Pabai F, Kermasha S, Morin A. Lipase from Pseudomonas fragi CRDA323: Partial purification, characterization and intersesterification of butter fat. Applied Microbiology Biotechnology. 1995; 43: 42-51.

11. Shimada Y, Tominaga Y. Purification and characterization of a novel strain-tolerant lipase from Fusarium heterosporum. Journal of Fermentation and Bioengineering. 1993; 75(5): 349-352.

12. Sztajer H, Maliszewska I, Wieczorek J. Production of exogenous lipases by bacteria, fungi and actinomycetes. Enzyme and Microbial Technology. 1998; 10: 492-497. 
13. Wadia T, Jain SK. Isolation, Screening and identification of Lipase Producing Fungi from Oil Contaminated Soil of Shani Mandir Ujjain. International Journal of Current Microbiology and Applied Sciences. 2017; 6(7): 1872-1878.

14. Wang J, Wang F, Shang J, Chen B. An efficient method for extraction of secreted proteins of a filamentous Fungus, Cryphonectria parasitica. Journal of Proteomics and Bioinformatics. 2011; 4: 125-128.

15. Iftikhar T, Niaz M, Jabeen R, Haq IU. 2011. Purification and characterization of extracellular lipases. Pakistan Journal of Botany. 2011; 43(3): 1541-1545.

16. Chahinian H, Vanot G, Ibrik A, Rugani N, Sarda L, Comeau LC. Production of extracellular lipases by Penicillium cyclopiumpurification and characterization of partial acylglycerol lipase. Bioscience, Biotechnology, and Biochemistry. 2000; 64: 215-222.

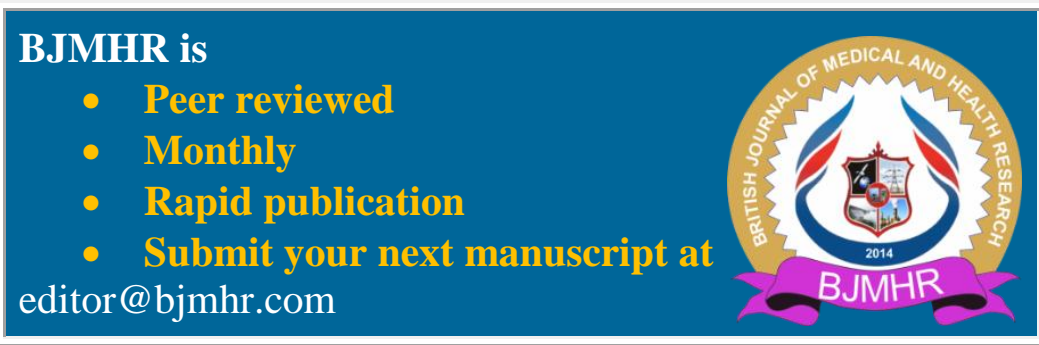

